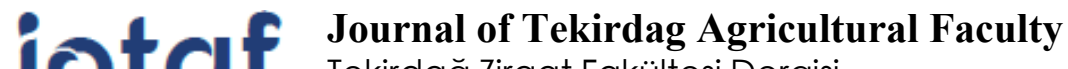 \\ Tekirdağ Ziraat Fakültesi Dergisi
}

\section{Santrifüj Gübre Dağıtma Makinesinde İki Farklı Tahrik Sisteminin Karşılaştırılması}

\author{
Comparison of Two Different Drive Systems on Fertilizer Broadcaster
}

\author{
Cengiz MERT ${ }^{1}$, Ali AYBEK ${ }^{2 *}$, Hamza KUZU ${ }^{3}$
}

$\ddot{\mathbf{O} z}$

Birçok tarım makinesi (toprak frezeleri, ekim, gübreleme, ilaçlama, sulama, biçme balyalama, silaj vb. makineler) traktör kuyruk milinden hareket alarak çalıştırılmaktadır. Traktör kuyruk milinden hareket, bir mafsallı mil (ara mil) ile tarım makinelerine aktarılmaktadır. Mafsallı mille hareket iletiminde, mekaniksel olumsuzlukların yanında, çalışma sırasında operatörün sağlık ve güvenliğini etkileyecek gürültü, titreşim ve mile dolanma riskleri de vardır. $\mathrm{Bu}$ çalışmada, santrifüj gübre dağıtma makinesine traktör kuyruk milinden verilen harekete alternatif olarak oluşturulan hidrolik bir sistemin, açık devre hidrolik sisteme sahip traktörün hidrolik sistemine bağlanarak çalışması sağlanmıştır. Her iki hareket iletimi (mafsallı mil ve hidrolik motor) durumlarında makinenin çalışma koşullarında; gübre dağılım düzgünlüğü, traktör yakıt tüketimi, oluşan gürülttü ve titreşim değerleri belirlenerek karşılaştırılmıştır. Mekanik sistemli çalışmada ortalama gürültü düzeyi; makine üzerinde $91.01(\mathrm{dBA})$, traktör kabini içerisinde ise $81.93(\mathrm{dBA})$ olarak belirlenmiştir. Hidrolik sistemli çalışmada ise ortalama gürültü düzeyi; makine üzerinde 81.15 (dBA), traktör kabini içerisinde ise 71.85 (dBA) olarak belirlenmiştir. Mekanik sistemin toplam titreşim ivmesi makine üzerinde $68.36 \mathrm{~m} \mathrm{~s}^{-2}$, traktör sürücü koltuğunda ise $3.23 \mathrm{~m} \mathrm{~s}^{-2}$ olmakta iken hidrolik sistemin toplam titreşim ivmesi makine üzerinde $60.02 \mathrm{~m} \mathrm{~s}^{-2}$, traktör sürücü koltuğunda ise $2.64 \mathrm{~m} \mathrm{~s}^{-2}$ olarak belirlenmiştir. Hidrolik sisteme sahip makinenin gübre dağılım düzgünlüğü açısından mekanik sisteme göre önemli bir farklılığı olmadığı, ancak yakıt tüketimi ve traktör sürücüsünün sağlığı açısından önemli olan gürültü ve titreșim değerleri bakımından daha uygun olduğu belirlenmiștir. Gübre dağıtma makinelerinin hidrolik sistem ile çalıștırılması makinenin hem verimini hem de etkinliğini arttırabilecek ergonomik açıdan da alternatif bir sistem olabilecektir. Traktör kuyruk milinden hareket alan diğer makinelerin de hidrolik motor uygulamaları ile çalıştırılmaları konusunda çalışmalar yapılabilir.

Anahtar Kelimeler: Hidrolik motor, Gübre dağıtma makinesi, Traktör hidrolik sistemi, Gübre dağılım düzgünlüğü, Traktör yakıt tüketimi

\footnotetext{
2*Sorumlu Yazar/Corresponding Author: Ali Aybek, Kahramanmaraş Sütçü İmam Üniversitesi, Ziraat Fakültesi, Biyosistem Mühendisliği Bölümü, Kahramanmaraş, Türkiye. E-mail: aaybek@ksu.edu.tr (iD) OrcID: 0000-0003-3036-8204

${ }^{1}$ Cengiz Mert, Ekinözü İlçe Tarım ve Orman Müdürlüğü, Kahramanmaraș, Türkiye. E-mail: cengiz.mert@tarimorman.gov.tr (DD OrcID: 0000-0001-7862-0793 ${ }^{3}$ Hamza Kuzu, Kahramanmaraș Sütçü İmam Üniversitesi, Ziraat Fakültesi, Biyosistem Mühendisliği Bölümü, Kahramanmaraş, Türkiye. E-mail: hamzakuzu@ksu.edu.tr (iD) OrcID: 0000-0001-8585-4467

Atıf/Citation: Mert, C., Aybek, A., Kuzu, H. Santrifüj Gübre Dağıtma Makinelerinde Hidrolik Motor Uygulaması. Tekirdağ Ziraat Fakültesi Dergisi, 18 (4), 660674.

(CBu çalıșma Tekirdağ Namık Kemal Üniversitesi tarafından Creative Commons Lisansı (https://creativecommons.org/licenses/by-nc/4.0/) kapsamında yayınlanmıştır. Tekirdağ 2021
} 


\begin{abstract}
Many agricultural machines (rotary tiller, planting, fertilizing, pesticide, irrigation, shearing, baling, silage machines etc.) are operated by getting motion from the tractor power takeoff. The motion from the tractor power takeoff (PTO) is transferred to the agricultural machines via an articulated shaft (the intermediate shaft). In motion transmission with an articulated shaft, in addition to mechanical adversities, there are risks of noise, vibration and entanglement which will affect the operator's health and safety during operation. In this study, a hydraulic system, which is formed as an alternative to the movement given by the PTO to the fertilizer broadcaster is connected to the hydraulic system of the tractor with open circuit hydraulic system. In the case of both motion transmissions (articulated shaft and hydraulic motor), operating conditions of the machine; fertilizer distribution uniformity, tractor fuel consumption, noise and vibration values were determined and compared. While mean noise level in mechanical system were determined as 91.01 (dBA) on the machine and $81.93(\mathrm{dBA})$ in the tractor cabine, mean noise level in hydraulic system were determined as $81.15(\mathrm{dBA})$ on the machine and $71.85(\mathrm{dBA})$ in the tractor cabine. While the total vibration acceleration of the mechanical system were determined as $68.36 \mathrm{~m} \mathrm{~s}^{-2}$ on the machine, $3.23 \mathrm{~m} \mathrm{~s}^{-2}$ on the tractor driver seat, the total vibration acceleration of the hydraulic system were determined as $60.02 \mathrm{~m} \mathrm{~s}^{-2}$ on the machine and $2.64 \mathrm{~m} \mathrm{~s}^{-2}$ on the tractor driver seat. It has been determined that the machine with hydraulic system does not differ significantly from the mechanical system in terms of fertilizer distribution uniformity, but it is more suitable in terms of fuel consumption and noise and vibration values that important for the health of the tractor driver. Operating the Fertilizer broadcaster machines with a hydraulic system can be an alternative system in terms of ergonomics that can increase both the efficiency and effectiveness of the machine. Works can be done to operate other machines driven from the PTO with hydraulic motor applications.
\end{abstract}

Keywords: Hydraulic motor, Fertilizer broadcaster, Tractor hydraulic system, Fertilizer distribution uniformity, Tractor fuel consumption. 


\section{Giriş}

Her yıl dünyada 10 milyonlarca ton kimyevi gübre, form olarak granül halde, tarla yüzeylerine elle veya makinelerle serpilerek toprakta gübreleme işlemi yapılmaktadır. Ülkemizde tarımın gelişimine bağlı olarak kimyevi gübre kullanımı gün geçtikçe artmaktadır. Bu bağlamda, 2017 yılı kimyevi gübre ihtiyacımız 2015 yılına göre \%8.7 oranında artarak 6.3 milyon tona ulaşmıştır (Anonim, 2019a). Ülkemizdeki tarım işletmelerinin geniş çaplı tarım arazilerinde granül kimyevi gübre uygulamalarında santrifüj gübre dağıtma makinelerinden yararlanılmaktadır. 2019 yılı tarım istatistiklerine göre ülkemizde 434755 adet kimyevi gübre dağıtma makinesi bulunmaktadir (Anonim, 2021).

Granül kimyevi gübrenin tarlaya atılmasında farklı çalışma sistemlerine sahip makineler kullanılmaktadır (Safer, 2008). Bunlar; 1) Traktör kuyruk milinden hareketli mafsallı bir mille çalıştırılan, 2) Tekerlekten hareket alarak çalıştırılan, 3) Hidrolik motor vasıtası ile hareketlendirilerek çalıştırılanlardır.

Bu makinelerden en yaygın kullanım alanına sahip olanı traktör kuyruk milinden mafsallı bir mille hareket alarak çalışan santrifüj gübre dağıtma makineleridir. Bunun nedeni makinelerdeki sistemin basit ve ucuz olmasının yanında gübreyi istenilen biçimde tarla yüzeyine dağıtabilmesidir. Santrifüj gübre dağıtma makinelerinde kullanılan bu hareket sisteminin bazı olumsuzlukları gözlenmektedir. Bunları sıralamak gerekirse operatörün makineyi traktöre bağlaması veya çalıştırması durumlarında mile dolanma riski, sistemin mekanik olmasından kaynaklı yüksek oranda gürültü, titreşim vb. risklerdir. İş sağlığı ve güvenliğini sağlamak için öncelikle kullanılacak makine ve sistemlerin kabul edilmiş sağlık ve güvenlik standartlarını karşılaması gerekmektedir (Temel ve Öztekin, 2020).

Hidrolik motor vasıtası ile hareketlendirilerek çalıştırılan makinelerdeki sistem yapı itibarı ile mafsallı mille hareketlendirilen sisteme göre karmaşık ve maliyeti yüksektir. Buna karşın bu sistem geleneksel mekanik sistemlere göre birçok olumlu çıktıyı (daha düşük değerlerde enerji, gürültü, titreşim sağlama) da içerisinde barındirmaktadır (Anonim, 2017a).

$\mathrm{Bu}$ çalışmada traktörden santrifüj gübre dağıtıma makinesine hareket aktarımı gerçekleştiren mafsallı mile alternatif olabilecek bir hidrolik sistem oluşturulmuştur. Bu sistem traktörün hidrolik pompasından gelen hidrolik enerjiyi traktörün hidrolik yağ çıkışlarından alarak hidrolik hortumlar vasıtası ile gübre dağıtma makinesi üzerine monte edilen hidrolik motora iletilmesi ve buraya iletilen hidrolik enerjinin yine hidrolik motor vasitası ile mekanik enerjiye dönüştürülmesiyle gerçekleştirilmiştir. Çalışmada kullanılan sisteme benzer olarak hidrolik motor ile hareketlendirilen makineler gelişmiş ülkelerde hali hazırda kullanılmaktadır. Ancak söz konusu sistem, bu çalışma ile ülkemizde ilk kez uygulanmıştır.

$\mathrm{Bu}$ çalışmanın genel amacı; santrifüj gübre dağıtma makinesine traktör kuyruk milinden verilen harekete alternatif olarak traktörün hidrolik sistemine bağlanan bir hidrolik motor yardımı ile hareketlendirilmesini sağlamaktır.

Spesifik amaçlar ise şunlardır;

- Santrifüj gübre dağıtma makinesinin hareketlendirilmesi için bir hidrolik sistem tasarımının gerçekleştirilmesi,

- Santrifüj gübre dağıtma makinesinin 2 farklı yönteme (mekanik, hidrolik) göre; arazi testleri ile gübre dağılım düzgünlüğü, yakıt, güç tüketimi değerlerini ve traktör operatörü üzerindeki etkisini (gürültü, titreşim) belirlemek,

- Santrifüj gübre dağıtma makinesi üzerinde yapılan konstrüktif değişikliğin, makine üzerinde olumlu ve olumsuz bir etki yapıp yapmadığını değerlendirmek ve değerlendirme sonucunda, daha sağlıklı ve güvenli çalışma şartlarının oluşturulması için öneriler geliştirmek,

- Gelecekte yapılacak olan benzer çalışmalara temel oluşturmak. 


\section{Materyal ve Metot}

\subsection{Materyal}

Denemelerde New Holland TD100D marka traktör kullanılmıştır. Çalışmada bu tip bir traktörün kullanılmasının amacı günümüz tarım tekniğinin gerekliliği olan yüksek hidrolik kapasiteyi bünyesinde barındırmasıdır. Denemede kullanılan traktörün hidrolik sistemi açık devre mantığı ile çalışmaktadır. Katalog verileri göz önüne alındığında, bu traktör arka hidrolik çıkışlarından azami 200 bar basınçta $50.1 \mathrm{~L} \mathrm{~min}^{-1}$ hidrolik yağ debisi sağlamaktadır.

Çalışmada 600 L kapasiteli, 8 ile 16 metre arası çalışma genişliğine sahip AgroFem marka çift diskli santrifüj gübre dağıtma makinesi kullanılmıştır. Makinenin genel ölçüleri; ağırlı̆̆ $210 \mathrm{~kg}$, dişli kutusu dişli oranı 1:1, genişlik $1500 \mathrm{~mm}$, uzunluk $1190 \mathrm{~mm}$ 'dir.

Gübre serpme makinesini traktör hidrolik sistemi ile eşzamanlı bir şekilde çalıştırabilmek için tasarımı gerçekleştirilen mekanik bağlantı kiti, hidrolik motor, hidrolik kontrol, hidrolik yağ ve hidrolik bağlantı elemanlarından oluşan hidrolik sistem tasarlanmıştır. Bu sistemde bulunan parçaların özellikleri ayrıntılı olarak bulgular kısmında yer almaktadır.

Denemelerde 20-20 NP granül gübre kullanılmıştır. Denemelerin ekim ayı içerisinde yapılması nedeniyle bu gübrenin kullanımı daha uygun görülmüştür.

Kuyruk mili torku ve kullanılan granül gübre serpme makinesinin, çalışabilmesi için ne kadarlık bir kuvvet gerektiği, Datum 420 PTO elektronik güç ölçüm cihazı yardımıyla ölçülmüştür (Anonim, 2016). Torkmetre; tork, devir ve buna bağlı oluşan gücü $\mathrm{kW}$ olarak göstermektedir. Bu ölçüm sonucu bulunan değerler 1ş̧̧̆ğnda hidrolik olarak hareketlendirilen sistemin de tasarımı şekillendirilmiştir. Tasarımı gerçekleştirilen yeni hidrolik sisteme göre çalışan gübre serpme makinesi sorunsuz bir şekilde çalıştı̆̆ gözlemlenmiştir.

Çalışma esnasında traktör operatörünün maruz kaldığı gürültü seviyesi ve gübre dağıtma makinesinin kabin dışındaki serbest ortama yaydığı gürültü düzeyi Brüel \& Kjaer 2250 marka cihazla belirlenmiştir (Anonim, 2019b).

Traktörün operatör koltuğu ve direkt olarak granül gübre dağıtma makinesinin gövdesinde yatay, dikey ve düşey düzlemede oluşan titreşimler, gübre dağıtma makinesinin disklerine hareket iletimi sağlayan şanzımana bağlanarak, PCE-VM 3D marka titreşim ölçüm cihazı yardımıyla belirlenmiştir (Anonim, 2015).

Gübre dağılım düzgünlüğünün belirlenmesi için toplanan granül gübre örneklerinin tartımında AND-HR-250 AZ marka mikro terazi kullanılmıştır (Anonim, 2019c). Mikro terazi $\pm 0.0001 \mathrm{~g}$ hassasiyette ölçüm yapabilmektedir.

Traktör hidrolik sisteminden gelen akışkan yağın basıncı PCE-SCJN 400 marka manometre ile belirlenmiştir (Anonim, 2017b). Dijital ekranlı elektronik esasa göre çalışan, manometre kullanılmasının temel amacı, günümüz araştırma tekniğine uygunluk ve bu çalışma açısından yüksek önem arz eden verilerin en hassas ve doğru bir biçimde belirleyebilmektir.

Granül gübre dağıtma makinesi tarafından tarla yüzeyine serpilen gübre örneklerinin toplanması amacıyla içi 100x100 bölüntü olacak biçimde 500x500 kare kutular kullanılmıştır (Şekil 1). Çalışmada kullanılan kare kutuların boyutları, ISO 5690/1 ve ASAE Standard (1998) S 341.2 çerçevesinde oluşturulmuştur.

Traktör kuyruk mili ile gübre dağıtma makinesi arasına bağlanan mafsallı milin ve hidrolik motorun gübre dağıtma makinesi hareket mili devri, PCE-151 marka devir ölçer ile belirlenmiştir (Anonim, 2017c). Söz konusu devir ölçerin kullanılmasının nedeni hem temas hem de dönel bir parçanın üzerine yapıştırılan yansıtıcı vasıtasıyla temassız olarak uzaktan optik algılama yöntemi ile devir tespiti yapabilmesidir. 

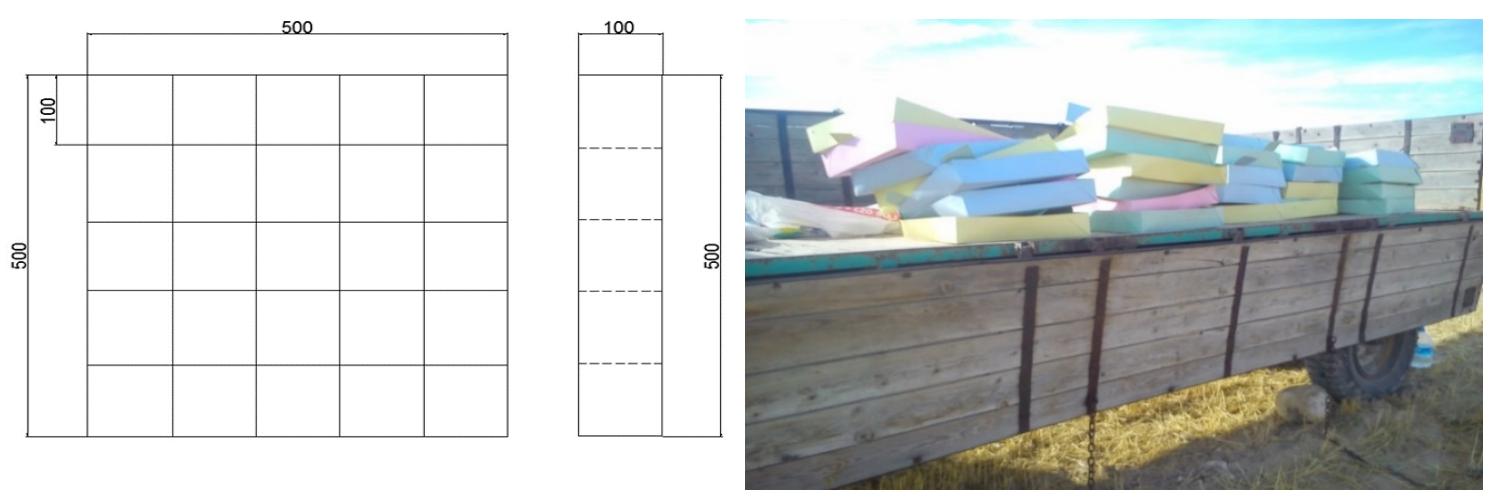

Figure 1. Square boxes with compartments

\section{Sekil 1. Bölümlü kare kutular}

\subsection{Metot}

Çalışmada, santrifüj gübre dağıtma makinesinin mekanik ve hidrolik hareket iletim sistemlerinin karşılaş̧ırılması yapılmıştır. Bunun için geleneksel mekanik sistemle çalışan bir makine kullanılmakla birlikte, aynı makinenin hidrolik sistemle çalsşacak şekilde hidrolik sistem oluşturulmuştur. Hidrolik olarak hareket alan sistemin kurulumu kısaca aşağıdaki sıralamaya göre gerçekleştirilmiştir.

Sistemin kurulumu için gerekli olan hidrolik bağlantı elemanları (hidrolik motor, valfler, hidrolik borular vb.) temin edilmiştir. Santrifüj gübre dağıtma makinesinin üzerinde bulunan mile hidrolik güç transferi ile makinenin hareketlenmesini sağlayacak mekanik bağlantı kiti imal edilerek makine üzerine montajı gerçekleştirilmiştir. Bağlantı kitinin 3 boyutlu görseli Şekil 2'de görülmektedir. Bu görselin ve çalışma çerçevesinde oluşturulan hidrolik sistem parçalarının tasarımı SolidWorks 2013 çizim programında gerçekleştirilmiş daha sonra ise montajlanan modeller KeyShot 4 programında render işlemine tabi tutularak görsel gerçeklik arttırılmıştır. Son olarak imalatı gerçekleştirilen ve standart olarak seçilen tüm parçalar montajlanarak santrifüj gübre dağıttma makinesi hidrolik güç yardımı ile hareketlendirilmiş̧ir.

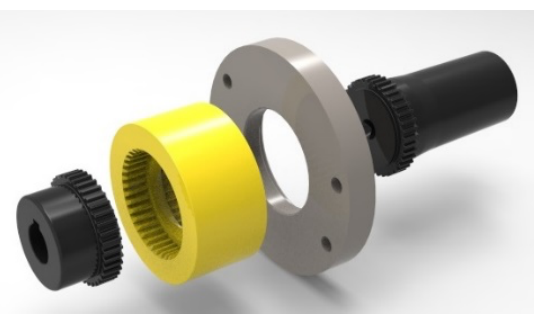

Figure 2. Mechanical connection kit transferring hydraulic power to the manure spreader

\section{Şekil 2. Hidrolik gücü gübre dağıtma makinesine aktaran mekanik bağlantı kiti}

Santrifüj gübre dağıtma makinesi arazi koşullarında testlere tabi tutularak, her iki yöntem (mekanik, hidrolik) için aşağıda sıralanan ölçümler standartlara uygun bir biçimde gerçekleştirilmiştir.

\subsubsection{Gübre dağılım düzgünlüğ̈̈nü̈n belirlenmesi}

Bu ölçümde; ilk olarak geleneksel sistemde makinenin gübre dağıtım düzgünlüğü belirlenmeye çalışılmıştır. $\mathrm{Bu}$ işlem şu şekilde gerçekleştirilmiş̧ir. Tarla yüzeyine 100x500x500 mm boyutlarındaki kare kutular yan yana dizilmiştir. Traktör tekerleğinin kutuları ezmemesi için ortada bulunan 2 adet kutunun sağından ve solundan ikişer tane kutu kaldırılmıştır. Daha sonra soldan başlanarak, kutular birden otuz ikiye kadar numaralandırılmıştır. İçerisi önceden granül ile gübre doldurulan gübre dağıtma makinesi, kuyruk mili devri $540 \mathrm{~min}^{-1}$ ' e ulaş̧ıktan sonra traktör hareket ettirilmiş ve gübrenin tarla yüzeyindeki kutuların içerisine dolması sağlanmıştır. Şekil 3 'te traktörle tarlada çalışırken gübre dağıtımı görülmektedir. 


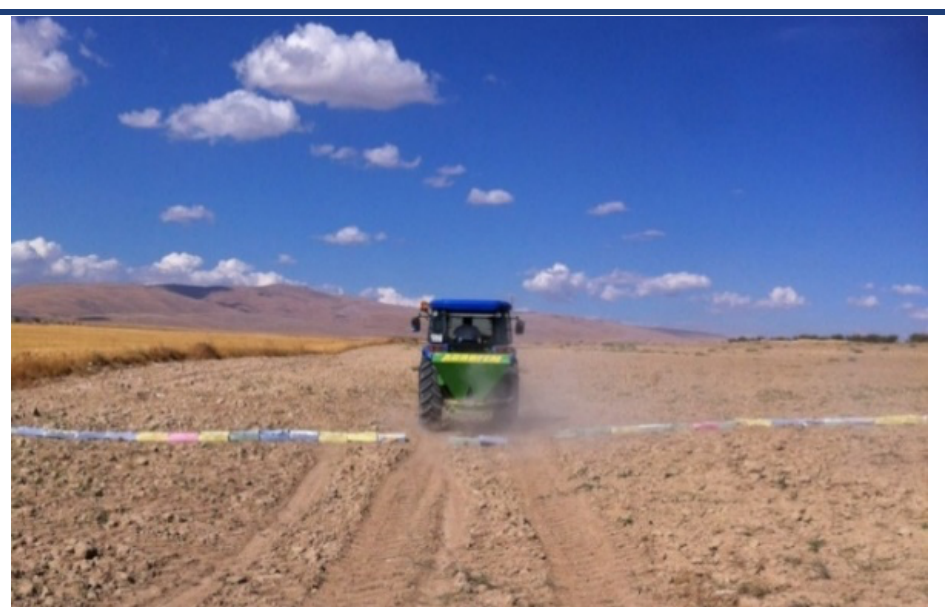

Figure 3. Manure distribution when working in the field with a tractor

\section{Şekil 3. Traktörle tarlada çalışırken gübre dağıtımı}

Kutuların içerisinde biriken gübre taneleri küçük poşetler içine alınarak kutu numarasına göre etiketlenmiş ve örnekler oluşturulmuştur. Toplanan örneklerin laboratuvar ortamındaki tartımları aşağıdaki sıralamaya göre gerçekleştirilmiştir:

- Örnek poşet içerisinde olmak kaydı ile uygun şekilde hassas teraziye yerleştirilmiş̧ir.

- Oluşan değer hassas terazinin dijital ekranından okunarak kayda geçirilmiştir.

- Bu işlem tüm örnekler için tekrarlanarak, net olmayan ağırlıkları belirlenmiş̧ir.

Tüm örneklerin net olmayan ağırlıkları belirlendikten sonra 1 adet boş poşetin ağırlığı hassas terazi yardımı ile ölçülmüş ve örneklerin net olmayan ağırlıklarından çıkarılarak, örneklerin gerçek ağılıkları belirlenmiştir.

Aynı işlemler hidrolik olarak hareket iletimi sağlanan sistemde de gerçekleştirilmiş ve gübre dağılım düzgünlüğü belirlenmeye çalışılmıştır. Bu işlemler ISO 5690-1: 1985 ve TS 2541 deney esaslarına uygun olacak biçimde 3 tekerrürlü olarak gerçekleştirilmiştir.

\subsubsection{Traktörün güç ve yakıt tüketiminin belirlenmesi}

Mekanik ve hidrolik sistemle hareketlendirilen santrifüj gübre dağıtma makinesine güç sağlayan traktörün kuyruk mili gücü değerleri elektronik esaslı torkmetre ile belirlenmiştir. Traktörün her iki sisteme göre yakıt tüketimi değerleri, traktör yakıt deposuna, her bir işlem için ölçülü kap yardımı ile ekleme yapılarak belirlenmiştir.

\subsubsection{Gürü̈ltü düzeyinin belirlenmesi}

Gürülttü düzeyinin belirlenmesinde ilk olarak geleneksel sisteme (mafsallı mille hareketlenen) göre yapılmış daha sonra hidrolik güçle hareketlenen sisteme de uygulanmıştır. Ölçümler deneme parselinde çalış1ılıken traktör kabini içerisinde sürücü kulak düzeyinde ve gübre dağıtma makinesi üzerinde yapılmıştır. Her bir ortam için 3 tekerrürlü olarak, her tekerrür için $13 \mathrm{kez}$ tekrarlanmış ve her ortam için toplamda 39 adet değer ölçülmüştür.

Traktör kabini içinde gürültü düzeyinin belirlenmesinde ölçüme başlamadan önce denemede kullanılan traktör uygun şekilde hazırlanmıştır. Santrifüj gübre dağıtma makinesi yüklü ve çalışır vaziyette, traktörün $540 \mathrm{~min}^{-1}$ kuyruk mili dönüsünü sağladığı katalog değerine ulaşıldığı anda traktör devri sabitlenmiş ve ölçüm cihazı traktör operatörü kulak seviyesinde tutularak, cihaz üzerinde bulunan başlat tuşuna basılarak ölçüme başlanmıştır. Ölçüm cihazının sayısal ekranında oluşan değerler 3 saniye arayla okunarak belirlenmiştir. Ortalama gürültü düzeyinin belirlenmesi bu veri ışığında değerlendirilmiştir.

Traktör kabini dışında gürültü düzeyinin belirlenmesinde ölçüme başlamadan önce traktör üzerinde gerekli kontroller yapılmıştır. Bu ölçüm, deneme parseli üzerinde ilerleme olmadan, traktörün $540 \mathrm{~min}^{-1}$ kuyruk mili dönüsünü sağladığı gerekli motor devrinde ve granül gübre dağıtma makinesi yüklü ve çalışır durumdayken, gürültü ölçüm cihazının gübre dağıtma makinesine 1 metre mesafede olacak şekilde gerçekleştirilmiştir. Kabin içindeki ölçümde olduğu gibi gerekli şartlar sağlandıktan sonra, cihaz üzerinde bulunan başlat tuşuna basılmış ve 

gürültü ölçümü sonucu oluşan değerler sayısal ekran yardımı ile 3 saniye arayla okunarak belirlenmiştir. Kabin dışı ortalama gürültü düzeyi bu verilere göre belirlenmiştir.

\subsubsection{Titreşim değerlerinin belirlenmesi}

Çalışmada mekanik ve hidrolik sistemle hareketlendirilen aynı santrifüj gübre dağıtma makinesi, bu araştırma için özel olarak tasarlanan hidrolik uyum kiti ve mafsallı mil yardımıyla farklı zaman aralıkları ile çalıştırılmış ve aşağıda sıralanan titreşim ölçümleri aynı şartlar sağlanarak yapılmıştır. Bu sistemlerin oluşturduğu titreşimlerin traktörün sürücü koltuğundan, operatöre hangi şiddette etki ettiği; ayrıca bu iki sistemin ortaya çıkardığı titreşimlerin makinenin konstrüksiyonu üzerine etkileri gözlemlenmiştir. Titreşim değerleri; hem traktör kabini içinde bulunan sürücü koltuğunda hem de granül gübre dağıtma makinesi üzerinde oluşan titreşimler dikkate alınarak 3 boyutlu (x, y, z) olarak belirlenmiştir.

Sürücü koltuğunda oluşan titreşimlerin belirlenmesi için kalibrasyon işlemi daha önceden yapılan 3 boyutlu titreşim ölçüm cihazının mıknatıslı 3 boyutlu algılayıcı probu, sürücü koltuğunun metal olan alt kısmına sabitlenmesi ile ölçüme başlanmıştır. Bu ölçüm, traktör deneme parselinde ilerlemekteyken ve granül gübre dağıtma makinesi çalışır vaziyetteyken gerçekleştirilmiştir.

Makine gövdesinde oluşan titreşim değerlerinin belirlenmesi, traktörün sabit granül gübre dağıtma makinesinin çalışır vaziyette olduğu durumda gerçekleştirilmiştir. Titreşim ölçüm cihazının mıknatıslı metal algılayıcı probu makine çalışır vaziyetteyken, makine gövdesinin üst kısmına sabit olarak yerleştirilmiş ve makine üzerinde oluşan titreşim değerleri belirlenmeye çalışılmıştır.

Titreşim değerlerinin belirlenmesinde TS EN ISO 5349-1 standardına göre frekans ağırlıklı ivmenin karelerinin ortalamasının karekökü (Root Mean Square - RMS) değeri (ahw) ele alınmaktadır (TS EN ISO 5349-1, 2005; Civelek ve Gülsoylu, 2010; Sabancı ve Sümer 2011). Ölçümlerde her titreşim koordinat ekseni için ivme değerleri ölçülmektedir. Üç eksenli frekans ağırlıklı ivmeleri birleştiren toplam titreşim ivmesi değerleri $\left(\mathrm{K}_{\mathrm{t}}\right)$ ise Eşitlik 1 ile belirlenmektedir (Babalık, 2007).

$$
K_{t}=\sqrt{K_{x}^{2}+K_{y}^{2}+K_{z}^{2}}
$$

Eşitlikte; $\mathrm{K}_{\mathrm{x}}$ : $\mathrm{x}$ eksenindeki, $\mathrm{K}_{\mathrm{y}}$ : y eksenindeki, $\mathrm{K}_{\mathrm{z}}$ : z eksenindeki frekans ağırlıklı ivmenin RMS değeri (m s${ }_{2}^{2}$ )'dir. Tüm eksenlerdeki ölçümler herhangi bir düzeltme yapılmadan ham veri şeklinde alınarak değerlendirilmiştir.

\subsubsection{Verilerin değerlendirilmesi}

Santrifüjlü gübre dağıtma makinesinin her iki tahrik (mekanik ve hidrolik) sisteminden elde edilen veriler (gübre dağılımı, güç ve yakıt tüketimi, gürültü ve titreşim) tablo ve grafiklere aktarılarak değerlendirilmiştir.

İki bağımsız grup arasındaki farklılığı test etmek için Mann-Whitney U testi kullanılabilir. Bu test bağımsız örnekler için uygulanan t-testlerinin parametrik olmayan alternatifidir. T-testinde olduğu gibi, iki grubun ortalamalarının karşılaştııılması yerine, Mann-Whitney U testi grupların medyanlarını karşılaştırır. Sürekli değişkenlerin, iki grup içerisinde değerlerini sıralı hale dönüştürür. Böylece, iki grup arasındaki sıralamanın farklı olup olmadığını değerlendirir (Demirgil, 2005). Her iki sistemde gübre dağılımı, gürültü ve titreşim değerleri arasında istatistiksel olarak önemli bir fark olup olmadığına karar vermek için SPSS programında önce verilerin normal dağılım testi yapılmıştır. Analiz sonucunda veriler normal dağılım göstermediği için parametrik olmayan testlerden Mann-Whitney U testinin uygun olduğu görülmüş ve bu teste göre her iki sistem arasındaki fark istatistiksel olarak karşılaştırılmıştır.

\section{Araştırma Sonuçları ve Tartışma}

\subsection{Hidrolik motor ile hareketlendirilen sistemin tasarımı ve kurulumu}

$\mathrm{Bu}$ çalışma kapsamında oluşturulan hidrolik hareket sistemi santrifüj gübre dağı̆tma makinesine monte edilmeden önce makinenin granül gübreyi dağıtabilmesi için gerekli güç ve konstrüktif değişiklikler mekanik sistem ile çalışan makine üzerinde yapılan testler sonucu elde edilen sayısal veriler kullanılarak hidrolik sisteme uyarlanması ile gerçekleştirilmiş̧ir. 
Hidrolik sistemin çalışabilmesi için gerekli olan güç belirlenmeye çalışılmıştır. Bunun için mekanik sistemle çalışan gübre dağıtma makinesiyle traktör kuyruk mili arasına mafsallı bir mil bağlanmıştır. Mafsallı milin gübre dağıtma makinesine bağlanan ucuna torkmetre ile test deney seti kurulmuştur. Daha sonra gübre dağıtma makinesi granül gübre ile doldurulmuş ve denemede kullanılan traktör sert beton zemin üzerinde sabit olarak çalışır duruma getirilmiştir. Torkmetre vasıtasıyla ölçülen sayısal veriler bilgisayarda bulunan özel bir program vasıtası ile kayda alınmıştır. Bu veriler Tablo l'de yer almaktadır.

Tablo l'de yer alan tork değerleri belirlendikten sonra granül gübre dağıtma makinesinin çalışır durumda ortalama olarak ne kadar mekanik güç tükettiği, Eşitlik 2 yardımıyla bulunmuştur (Özmerzi ve ark., 2004; Sabancı ve ark., 2010).

$\mathrm{Nm}=\frac{M d * n}{9550}$

Burada;

$\mathrm{Nm} \quad$ : Motor mekanik gücü $(\mathrm{kW})$,

Md : Ölçülen tork değeri (Nm),

n $\quad$ : Mil devir sayısı $\left(540 \mathrm{~min}^{-1}\right)^{\prime} \mathrm{d} ı$.

Bulunan mekanik güç değeri $4.941 \mathrm{~kW}$ olmaktadır. Bu değer kullanılarak, hidrolik gücün gübre dağıtma makinesi üzerine aktarılmasında en önemli unsur olan hidrolik motorun seçimi gerçekleştirilmiştir.

Tablo 1. Torkmetre ile traktör kuyruk milinden 540 min $^{-1}$ 'de ölçülen tork değerleri (Nm)

Table 1. Torque values (Nm) measured at 540 min $^{-1}$ from the tractor PTO shaft with torque meter

\begin{tabular}{cccc}
\hline Ölçüm & Oluşan değer & Ölçüm & Oluşan değer \\
\hline 1 & 85.83 & 8 & 75.23 \\
2 & 96.71 & 9 & 85.88 \\
3 & 95.59 & 10 & 82.76 \\
4 & 85.34 & 11 & 89.13 \\
5 & 82.74 & 12 & 91.82 \\
6 & 81.85 & 13 & 87.68 \\
7 & 89.81 & 14 & 93.15 \\
\hline
\end{tabular}

Hidrolik olarak hareketlendirilen sistem; mekanik bağlantı kiti, hidrolik motor, akış kontrol valfi, basınç ayar valfi, flanşlı geçme, dişli kovan, elektronik manometre ve hidrolik bağlantı elemanlarından (1:2 jak, hidrolik yağ hortumları vb.) oluşmaktadır. Bu hidrolik ayar ve bağlantı elemanlarının seçimi denemelerde kullanılan traktörün hidrolik kapasitesi ve seçilen hidrolik motorun maksimum hidrolik debide ortaya koyduğu basınç ve güç değerlerine göre belirlenmiştir. Hidrolik motor gücü Eşitlik 3 yardımıyla belirlenmiştir (Anonim, 2018). Bu çalışma için yüksek hidrolik güce sahip bir traktörün gerekliliği bir kez daha ortaya konulmuştur.

$N_{h d}=\frac{\mathrm{P} * \mathrm{Q}}{600}$

Burada;

$\mathrm{N}_{\mathrm{hm}} \quad$ : Hidrolik motor gücü $(\mathrm{kW})$,

P : Pompa basinc1 (bar),

Q : Pompa debisi $\left(\mathrm{L} \mathrm{min}^{-1}\right)^{\prime}$ dir.

Hidrolik motor gücünün belirlenmesinde pompa verimi $\% 90$ olarak alınmıştır.

$\mathrm{Bu}$ çalışma çerçevesinde yukarıda sıralanan hidrolik sisteme ait elemanlar, birbiri ile uyumlu bir şekilde çalışır hale getirilerek Şekil 4'te 3 boyutlu görseli bulunan hidrolik sistem oluşturulmuştur. 


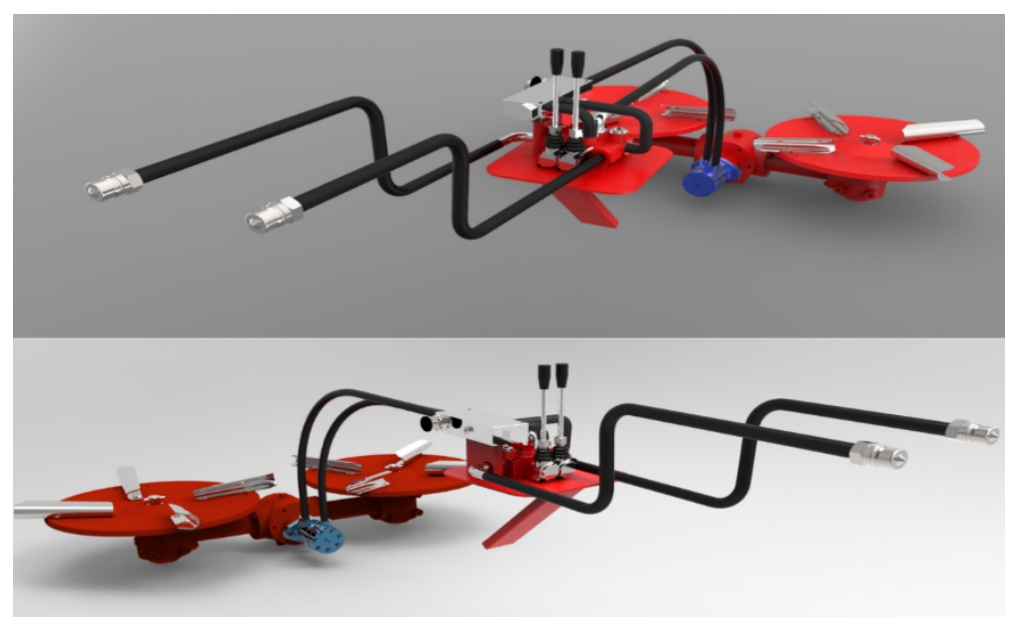

Figure 4. Hydraulic moving system in fertilizer broadcasters

Şekil 4. Santrifüj gübre dağıtma makinesine hidrolik olarak hareket veren sistem

\subsection{Mekanik ve hidrolik sistem açısından gübre dağıtma makinesinin performans değerleri}

Gübre dağıtma makinesinin her iki sistem (mekanik, hidrolik) için gübre dağılımları ve traktör yakıt tüketimi değerleri belirlenmiştir. İki sistem arasında arazi şartlarında 3 tekerrürlü olacak biçimde, rüzgarsız durağan hava koşullarında tarla denemeleri yapılmıştır. Bu denemeler sonucu tarla yüzeyine konulan, kutularda biriken gübre miktarları Tablo 2'de yer almaktadır.

Tablo 2. Mekanik ve hidrolik sistemde gübre kutularında biriken granül gübre miktarları (g)

Table 2. The amount of granular fertilizer $(g)$ accumulated in the manure boxes in the mechanical and hydraulic system

\begin{tabular}{|c|c|c|c|c|c|c|}
\hline \multicolumn{3}{|c|}{ Mekanik sistem } & \multirow{2}{*}{ Gübre kutuları } & \multicolumn{3}{|c|}{ Hidrolik sistem } \\
\hline 1. Deneme & 2. Deneme & 3. Deneme & & 1. Deneme & 2. Deneme & 3. Deneme \\
\hline 0.0080 & 0.0098 & 0.0110 & Kutu-7 & 0.6526 & 0.5674 & 0.5226 \\
\hline 0.4031 & 0.4232 & 0.3424 & Kutu-8 & 2.2227 & 2.2672 & 2.3685 \\
\hline 2.0889 & 2.1899 & 2.0418 & Kutu-9 & 5.7511 & 5.0324 & 5.0562 \\
\hline 5.2939 & 6.0588 & 5.1735 & Kutu-10 & 5.5623 & 5.3651 & 5.2748 \\
\hline 6.1443 & 6.2693 & 6.3308 & Kutu-11 & 6.1594 & 6.0415 & 6.0562 \\
\hline 6.1074 & 6.2488 & 6.0426 & Kutu-12 & 7.1189 & 6.3017 & 5.9674 \\
\hline 7.2214 & 6.9589 & 7.2506 & Kutu-13 & 5.5906 & 5.0762 & 5.2572 \\
\hline 4.3732 & 4.4694 & 4.3221 & Kutu-14 & 4.0155 & 4.0449 & 4.0424 \\
\hline 4.2312 & 4.3699 & 4.1575 & Kutu-15 & 4.2820 & 4.3695 & 4.2585 \\
\hline 7.5671 & 7.7163 & 7.4015 & Kutu-16 & 7.1051 & 7.9218 & 7.8291 \\
\hline 6.5616 & 6.7966 & 6.7024 & Kutu-17 & 7.3997 & 6.8979 & 7.2630 \\
\hline 6.1550 & 6.2574 & 6.0564 & Kutu-18 & 5.6412 & 5.3651 & 5.2624 \\
\hline 6.6960 & 6.9064 & 6.5695 & Kutu-19 & 6.5359 & 6.2660 & 6.3651 \\
\hline 8.1520 & 8.6195 & 8.0312 & Kutu-20 & 6.7116 & 5.9312 & 5.9189 \\
\hline 6.1427 & 6.1715 & 6.1582 & Kutu-21 & 5.9217 & 5.6314 & 5.9112 \\
\hline 3.2005 & 3.3224 & 3.1722 & Kutu-22 & 4.9347 & 4.9232 & 4.7258 \\
\hline 2.3548 & 2.4558 & 2.3584 & Kutu-23 & 3.7992 & 3.0417 & 3.2610 \\
\hline 0.7914 & 0.8015 & 0.7234 & Kutu-24 & 2.7787 & 2.1694 & 2.4565 \\
\hline 0.0892 & 0.1922 & 0.1222 & Kutu-25 & 0.6960 & 0.6309 & 0.3805 \\
\hline 4.399 & 4.538 & 4.366 & Ortalama & 4.888 & 4.623 & 4.640 \\
\hline 19 & 19 & 19 & n (örnek sayıs1) & 19 & 19 & 19 \\
\hline 2.643 & 2.703 & 2.635 & S (standart sapma) & 2.007 & 1.983 & 1.997 \\
\hline 0.600 & 0.595 & 0.603 & $\begin{array}{c}\mathrm{CV} \text { (varyasyon } \\
\text { katsayıs1) }\end{array}$ & 0.410 & 0.428 & 0.430 \\
\hline
\end{tabular}

Tarla çalışmaları sonucu; mekanik sistemli santrifüj gübre makinesinin gübre dağılım düzgünlüğü Şekil 5'te, hidrolik sistemli santrifüj gübre makinesinin gübre dağılım düzgünlüğü ise Şekil 6'da yer almaktadır. 
Dağı̆lım desenleri incelendiğinde, 'W' şekilli bir görünüm ortaya çıkmaktadır. Dağılım desenlerinin normal dağılıma benzer olması, gübre dağılım düzgünlüğü bakımından istenilen özelliklerdendir (Grift, 2000). Normal dağılıma benzer olamayan ' $\mathrm{W}$ ' şekilli dă̆ılım desenleri örtme payındaki değişikliklere karşı çok hassas olduklarından gübre dağılım düzgünlügü̈ bakımından istenmeyen desen tiplerindendir (Glover ve Baird, 1973). $\mathrm{Bu}$ tür desenlerde, tarlada çalışma sırasında gidiş ve dönüşlerde iş genişliğindeki küçük sapmalardan dolayı, CV değerleri bir anda çok yüksek değerlere ulaşmakta ve dağılım düzgünlüğü bozulmaktadır. Tablo 2'de verilen iki sistemin karşılaştırıldığı CV değerleri 1şı̆̆ında hidrolik sistemde oluşan değerler mekanik sistemde oluşan değerlere göre daha az farklar oluşmaktadır. Şekil 5 ve Şekil 6'da görüldüğü gibi gübre dağılımının düzgünlüğü hidrolik sistemde, mekanik sisteme nazaran normal dağllıma yakın bir görünümdedir. Bu verilere göre hidrolik sistemin gübre dağılım düzgünlüğü açısından mekanik sisteme göre üstün olduğu görülmektedir. Ancak yapılan Mann-Whitney U testine göre aradaki fark istatistiksel olarak önemsizdir ( $\mathrm{P}>0.05)$.

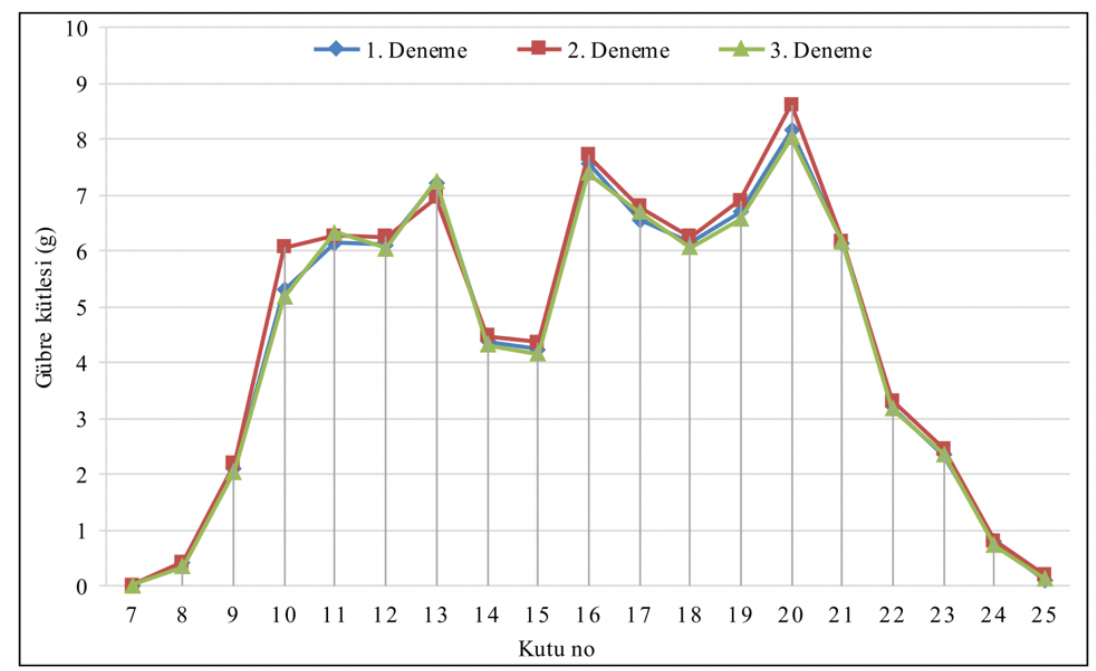

Figure 5. Fertilizer distribution uniformity of the fertilizer broadcaster with mechanical system

Şekil 5. Mekanik sistemli santrifüj gübre makinesinin gübre dağılım düzgünlüğ̈̈

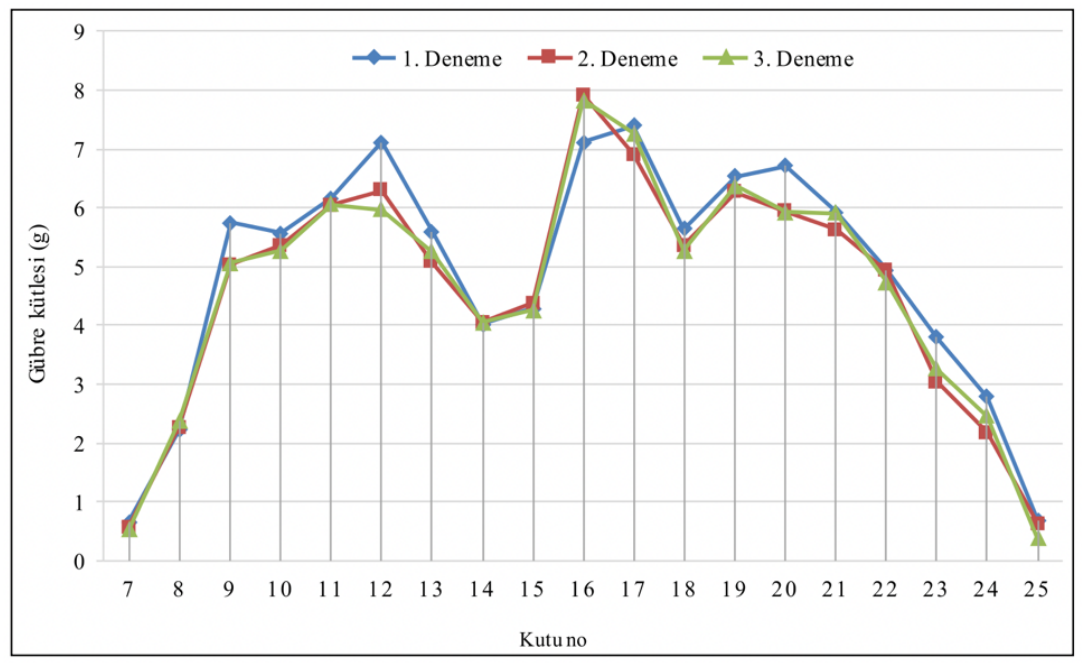

Figure 6. Fertilizer distribution uniformity of the fertilizer broadcaster with hydraulic system

\section{Şekil 6. Hidrolik sistemli santrifüj gübre makinesinin gübre dağ̆llım düzgünlüğ̈̈}

Tarla şartlarında iki sistemin çalışması sonucu traktörün yakıt tüketimi Tablo 3’te görülmektedir. Hidrolik sistemli gübre dağıma makinesi ile yapılan tarla demelerinde daha düşük bir hızla granül gübre arazi yüzeyine istenilen şekilde dağıtılabilmektedir. Pratik açıdan çok fark olmamasına rağmen hidrolik sistemli santrifüj gübre dağıtma makinesinin yakıt tüketimi $10.44 \mathrm{~L} \mathrm{~h}^{-1}$ mekanik sistemli gübre dağıtma makinesinin yakıt tüketimi ise 
Santrifüj Gübre Dağıtma Makinesinde İki Farklı Tahrik Sisteminin Karşılaştırılması $10.71 \mathrm{~L} \mathrm{~h}^{-1}$ olmaktadır (Tablo 3). Yakıt tüketiminin azalması Çetin ve ark. (2020) dikkat çektiği, tarımdaki karbondioksit emisyonlarının neden olduğu çevre kirliliğinde de bir azalma eğilimi göstermesine yardımcı olabilecektir.

Tablo 3. Traktörün yakıt tüketim değerleri

Table 3. Tractor fuel consumption values

\begin{tabular}{lcc}
\hline Parametreler & $\begin{array}{l}\text { Mekanik sistemli gübre dağıtma } \\
\text { makinesi ile çalışmada }\end{array}$ & $\begin{array}{l}\text { Hidrolik sistemli gübre dağıtma } \\
\text { makinesi ile çalışmada }\end{array}$ \\
\hline Alınan yol $(\mathrm{m})$ & 200.00 & 200.00 \\
İş genişliği $(\mathrm{m})$ & 12.00 & 12.00 \\
Çalışma hızı $\left(\mathrm{km} \mathrm{h}^{-1}\right)$ & 8.57 & 8.40 \\
Yakıt tüketimi $\left(\mathrm{L} \mathrm{h}^{-1}\right)$ & 10.71 & 10.44 \\
\hline
\end{tabular}

\subsection{Iki Sistemin Ergonomik Olarak Değerlendirilmesi}

Bu çalışma için iki sistem arasında arazi şartlarında 3 tekerrürlü olacak biçimde gürültü ve titreşim düzeyi ölçümleri yapılmıştır.

\subsubsection{Gürü̈ltü düzeyi değerleri}

İki sistemin granül gübre dağıtma makinesi üzerindeki gürültü değerleri Tablo 4'te, traktör kabini içerisindeki gürültü değerleri ise Tablo 5'te verilmiştir.

Mekanik sistemli çalışmada ortalama gürültü düzeyi; makine üzerinde 91.01 (dBA), traktör kabini içerisinde ise 81.93 (dBA) olarak belirlenmiştir. Hidrolik sistemli çalışmada ise ortalama gürültü düzeyi; makine üzerinde 81.15 (dBA), traktör kabini içerisinde ise 71.85 (dBA) olarak belirlenmiştir (Tablo 4 ve 5).

Çalışanların gürültü ile ilgili risklerden korunmalarına dair yönetmeliğe göre, en düşük maruziyet eylem değeri 80 dBA, en yüksek maruziyet eylem değeri 85 dBA, maruziyet sınır değeri 87 dBA'dır (Anonim, 2013). Buna göre mekanik sistemli çalışmada makine üzerinde oluşan gürültü değerleri (91.01 dBA), en yüksek maruziyet eylem değerini (85 dBA) ve maruziyet sınır değerini (87 dBA) aşmakta, traktör kabini içerisindeki gürültü değeri (81.93 dBA) ise en düşük maruziyet eylem değerini ( $80 \mathrm{dBA})$ aşmaktadır. Hidrolik sistemli çalışmada ise makine üzerinde oluşan gürültü değeri (81.15 dBA) en düşük maruziyet eylem değerini ( $80 \mathrm{dBA})$ aşmakta, traktör kabini içerisinde oluşan gürültü (71.85 dBA) ise en düşük maruziyet eylem değerinin ( $80 \mathrm{dBA})$ yaklaşık $10 \mathrm{dBA}$ altında kalmaktadır. Yapılan Mann-Whitney U testine göre her iki sistemin hem makine üzerinde hem de traktör kabini içerisinde oluşan gürültü değerleri istatistiksel olarak önemli bulunmuştur $(\mathrm{P}<0.05)$.

Tablo 4. Iki sistemde makine üzerinde oluşan gürültü değerleri (dBA)

Table 4. Noise values (dBA) on the machine in two systems

\begin{tabular}{cccccc}
\hline 1. Deneme & $\begin{array}{c}\text { Mekanik sistem } \\
\text { 2. Deneme }\end{array}$ & 3. Deneme & 1. Deneme & $\begin{array}{c}\text { Hidrolik sistem } \\
\text { 2. Deneme }\end{array}$ & 3. Deneme \\
\hline 90.0 & 89.0 & 90.0 & 80.0 & 81.0 & 80.0 \\
92.0 & 91.0 & 91.0 & 81.0 & 82.0 & 81.0 \\
91.0 & 90.0 & 89.0 & 83.0 & 81.0 & 80.0 \\
90.5 & 89.5 & 89.5 & 80.0 & 82.0 & 82.0 \\
93.0 & 92.0 & 91.0 & 82.5 & 82.0 & 84.5 \\
92.0 & 91.0 & 92.0 & 80.0 & 81.0 & 81.0 \\
91.0 & 90.0 & 90.0 & 80.0 & 80.0 & 82.0 \\
92.0 & 92.0 & 89.0 & 79.0 & 81.0 & 80.0 \\
91.0 & 93.0 & 92.0 & 84.0 & 81.0 & 80.0 \\
93.0 & 90.0 & 93.0 & 80.5 & 80.0 & 81.0 \\
90.0 & 90.0 & 91.0 & 81.0 & 82.0 & 82.0 \\
92.0 & 91.0 & 92.0 & 80.0 & 80.0 & 80.0 \\
92.0 & 92.0 & 90.0 & 82.0 & 83.0 & Toplam örnek say1s1 13 \\
\hline
\end{tabular}


JOTAF/ Journal of Tekirdag Agricultural Faculty, 2021, 18(4)

Tablo 5. İki sistemde traktör kabini içerisinde oluşan gürültü değerleri (dBA)

Table 5. Noise values (dBA) in the tractor cabin in two systems

\begin{tabular}{cccccc}
\hline & Mekanik sistem & & \multicolumn{3}{c}{ Hidrolik sistem } \\
1. Deneme & 2. Deneme & 3. Deneme & 1. Deneme & 2. Deneme & 3. Deneme \\
\hline 80.0 & 79.0 & 81.0 & 72.0 & 73.0 & 72.0 \\
82.0 & 81.0 & 79.0 & 70.5 & 74.0 & 71.0 \\
81.0 & 82.0 & 78.0 & 73.0 & 72.0 & 74.0 \\
81.5 & 80.0 & 79.0 & 72.0 & 71.0 & 72.0 \\
81.0 & 82.0 & 83.0 & 72.0 & 70.0 & 72.0 \\
82.0 & 81.0 & 82.0 & 74.0 & 72.0 & 71.0 \\
83.0 & 80.0 & 82.0 & 73.0 & 70.0 & 73.0 \\
81.0 & 80.0 & 81.0 & 72.0 & 74.0 & 72.0 \\
84.0 & 81.0 & 83.0 & 71.5 & 72.0 & 71.0 \\
83.0 & 84.0 & 82.0 & 70.0 & 71.0 & 70.5 \\
85.0 & 83.0 & 84.0 & 71.0 & 73.0 & 70.0 \\
84.0 & 85.0 & 84.0 & 72.0 & 71.0 & 72.0 \\
84.5 & 83.5 & 84.0 & 70.0 & 75.0 & \\
\hline
\end{tabular}

Toplam örnek sayısı 13

Ortalama gürültü düzeyleri (dBA)

81.93

71.85

\subsubsection{Titreşim düzeyi dĕgerleri}

Bu çalışmada iki sistemde (mekanik ve hidrolik) arazide çalışırken makine üzerinde ve sürücü koltuğunda oluşan titreşim değerleri belirlenmiştir. İki sistemin makine üzerindeki titreşim değerleri Tablo 6 ' da, traktör sürücü koltuğundaki titreşim değerleri ise Tablo 7'de verilmiştir.

Tablo 6. İki sistemde arazide çalışırken makine üzerinde oluşan titreşim dĕgerleri $\left(m \mathrm{~s}^{-2}\right)$

Table 6. Vibration values $\left(\mathrm{m} \mathrm{s}^{-2}\right)$ on the machine while working in the field in two systems

\begin{tabular}{|c|c|c|c|c|c|c|c|c|c|c|c|c|c|c|c|c|c|}
\hline \multicolumn{9}{|c|}{ Mekanik sistem } & \multicolumn{9}{|c|}{ Hidrolik sistem } \\
\hline \multicolumn{3}{|c|}{ 1. Deneme } & \multicolumn{3}{|c|}{ 2. Deneme } & \multicolumn{3}{|c|}{ 3. Deneme } & \multicolumn{3}{|c|}{ 1. Deneme } & \multicolumn{3}{|c|}{ 2. Deneme } & \multicolumn{3}{|c|}{ 3. Deneme } \\
\hline $\mathrm{x}$ & $\mathrm{y}$ & $\mathrm{z}$ & $\mathrm{x}$ & $\mathrm{y}$ & $\mathrm{z}$ & $\mathrm{x}$ & $\mathrm{y}$ & $\mathrm{z}$ & $\mathrm{x}$ & $\mathrm{y}$ & $\mathrm{z}$ & $\mathrm{x}$ & $\mathrm{y}$ & $\mathrm{z}$ & $\mathrm{x}$ & $\mathrm{y}$ & $\mathrm{z}$ \\
\hline 25.0 & 21.0 & 53.0 & 24.0 & 22.0 & 57.0 & 18.0 & 19.0 & 47.0 & 20.9 & 19.9 & 50.3 & 20.7 & 18.0 & 51.2 & 21.1 & 18.9 & 52.1 \\
\hline 29.0 & 17.0 & 54.0 & 28.0 & 19.0 & 55.0 & 31.0 & 25.0 & 60.0 & 21.3 & 20.0 & 47.3 & 21.0 & 19.1 & 49.8 & 18.3 & 19.1 & 48.2 \\
\hline 31.0 & 26.0 & 61.0 & 27.0 & 25.0 & 71.0 & 27.0 & 19.0 & 59.0 & 18.5 & 17.3 & 50.6 & 18.9 & 18.0 & 50.7 & 20.7 & 17.9 & 54.2 \\
\hline 18.0 & 19.0 & 44.0 & 22.0 & 19.0 & 49.0 & 29.0 & 21.0 & 72.0 & 22.1 & 20.1 & 49.9 & 22.7 & 20.1 & 59.2 & 19.7 & 19.1 & 50.1 \\
\hline 31.0 & 18.0 & 77.0 & 32.0 & 25.0 & 69.0 & 25.0 & 18.0 & 61.0 & 21.7 & 18.3 & 57.3 & 18.9 & 18.0 & 57.2 & 21.5 & 22.7 & 58.5 \\
\hline 25.0 & 21.0 & 64.0 & 27.0 & 20.0 & 61.0 & 22.0 & 19.0 & 55.0 & 19.8 & 18.1 & 51.5 & 19.9 & 18.5 & 52.1 & 20.6 & 19.7 & 55.4 \\
\hline 28.0 & 18.0 & 63.0 & 29.0 & 21.0 & 62.0 & 26.0 & 20.0 & 58.0 & 20.7 & 17.2 & 50.6 & 22.1 & 19.1 & 55.9 & 23.0 & 21.5 & 60.9 \\
\hline
\end{tabular}

$$
\text { Ortalama titreşim düzeyleri }\left(\mathrm{m} \mathrm{s}^{-2}\right)
$$

\begin{tabular}{cccccc}
$\mathrm{x}$ & $\mathrm{y}$ & $\mathrm{z}$ & $\mathrm{x}$ & $\mathrm{y}$ & $\mathrm{z}$ \\
\hline 26.4 & 20.6 & 59.6 & 20.7 & 19.1 & 53.0 \\
\hline
\end{tabular}

Mekanik sistemli çalışmada ortalama titreşim düzeyleri; makine üzerinde x ekseninde $26.4 \mathrm{~m} \mathrm{~s}^{-2}$, y ekseninde $20.6 \mathrm{~m} \mathrm{~s}^{-2}$, z ekseninde $59.6 \mathrm{~m} \mathrm{~s}^{-2}$; traktör sürücü koltuğunda $\mathrm{x}$ ekseninde $1.1 \mathrm{~m} \mathrm{~s}^{-2}$, y ekseninde $1.4 \mathrm{~m} \mathrm{~s}^{-2}, \mathrm{z}$ ekseninde $2.7 \mathrm{~m} \mathrm{~s}^{-2}$ olarak belirlenmiştir. Hidrolik sistemli çalışmada ortalama titreşim düzeyleri; makine üzerinde x ekseninde $20,7 \mathrm{~m} \mathrm{~s}^{-2}$, y ekseninde $19.1 \mathrm{~m} \mathrm{~s}^{-2}$, z ekseninde $53.0 \mathrm{~m} \mathrm{~s}^{-2}$; traktör sürücü koltuğunda x ekseninde 0.7 $\mathrm{m} \mathrm{s}^{-2}$, y ekseninde $1.1 \mathrm{~m} \mathrm{~s}^{-2}$, $\mathrm{z}$ ekseninde $2.3 \mathrm{~m} \mathrm{~s}^{-2}$ olarak belirlenmiştir (Tablo 6 ve 7). 
Santrifüj Gübre Dağıtma Makinesinde İki Farklı Tahrik Sisteminin Karşılaştırılması

Tablo 7. İki sistemde arazide çalışırken sürücü koltuğunda oluşan titreşim değerleri $\left(m \mathrm{~s}^{-2}\right)$

Table 7. Vibration values $\left(\mathrm{m} \mathrm{s}^{-2}\right)$ occurring in the driver's seat while working in the field in two systems

\begin{tabular}{|c|c|c|c|c|c|c|c|c|c|c|c|c|c|c|c|c|c|}
\hline \multicolumn{9}{|c|}{ Mekanik sistem } & \multicolumn{9}{|c|}{ Hidrolik sistem } \\
\hline \multicolumn{3}{|c|}{ 1. Deneme } & \multicolumn{3}{|c|}{ 2. Deneme } & \multicolumn{3}{|c|}{ 3. Deneme } & \multicolumn{3}{|c|}{ 1. Deneme } & \multicolumn{3}{|c|}{ 2. Deneme } & \multicolumn{3}{|c|}{ 3. Deneme } \\
\hline $\mathrm{x}$ & $\mathrm{y}$ & $\mathrm{z}$ & $\mathrm{x}$ & $\mathrm{y}$ & $\mathrm{z}$ & $\mathrm{x}$ & $\mathrm{y}$ & $\mathrm{z}$ & $\mathrm{x}$ & $\mathrm{y}$ & $\mathrm{z}$ & $\mathrm{x}$ & $\mathrm{y}$ & $\mathrm{z}$ & $\mathrm{x}$ & $\mathrm{y}$ & $\mathrm{z}$ \\
\hline 0.4 & 0.3 & 0.6 & 0.4 & 0.4 & 0.7 & 3.2 & 5.3 & 6.1 & 0.2 & 0.3 & 0.5 & 0.3 & 0.6 & 2.9 & 0.1 & 0.2 & 0.4 \\
\hline 0.5 & 0.4 & 1.9 & 0.3 & 0.5 & 1.7 & 0.5 & 0.6 & 1.7 & 0.4 & 0.3 & 0.7 & 1.9 & 4.1 & 5.7 & 0.5 & 0.4 & 0.8 \\
\hline 0.5 & 0.4 & 1.5 & 1.2 & 0.9 & 5.8 & 0.4 & 0.5 & 1.2 & 0.3 & 0.2 & 1.3 & 0.2 & 0.3 & 1.2 & 0.2 & 0.3 & 0.9 \\
\hline 0.5 & 0.6 & 0.8 & 0.4 & 0.5 & 0.6 & 0.6 & 0.4 & 0.6 & 1.2 & 1.7 & 3.7 & 0.1 & 0.2 & 0.4 & 2.1 & 3.7 & 5.5 \\
\hline 1.3 & 1.8 & 6.7 & 1.1 & 1.7 & 3.5 & 0.5 & 0.6 & 1.5 & 2.3 & 4.8 & 5.2 & 0.4 & 0.5 & 1.7 & 1.4 & 1.6 & 2.9 \\
\hline 0.6 & 0.2 & 0.7 & 3.2 & 5.1 & 6.7 & 0.9 & 0.7 & 3.5 & 0.3 & 0.3 & 0.6 & 1.1 & 1.2 & 4.5 & 0.7 & 0.6 & 3.9 \\
\hline 3.3 & 5.6 & 6.3 & 2.8 & 1.9 & 2.5 & 1.2 & 1.5 & 2.8 & 0.7 & 0.6 & 1.9 & 0.5 & 0.4 & 0.9 & 0.4 & 0.5 & 1.7 \\
\hline \multicolumn{18}{|c|}{ Ortalama titreşim düzeyleri $\left(\mathrm{m} \mathrm{s}^{-2}\right)$} \\
\hline \multicolumn{3}{|c|}{$\mathrm{x}$} & \multicolumn{3}{|c|}{$\mathrm{y}$} & \multicolumn{3}{|c|}{$\mathrm{z}$} & \multicolumn{3}{|c|}{$\mathrm{x}$} & \multicolumn{3}{|c|}{$\mathrm{y}$} & \multicolumn{3}{|c|}{$\mathrm{z}$} \\
\hline \multicolumn{3}{|c|}{1.1} & \multicolumn{3}{|c|}{1.4} & \multicolumn{3}{|c|}{2.7} & \multicolumn{3}{|c|}{0.7} & \multicolumn{3}{|c|}{1.1} & \multicolumn{3}{|c|}{2.3} \\
\hline
\end{tabular}

$\mathrm{Bu}$ değerlere göre mekanik sistemin toplam titreşim ivmesi makine üzerinde $68.36 \mathrm{~m} \mathrm{~s}^{-2}$, traktör sürücü koltuğunda ise $3.23 \mathrm{~m} \mathrm{~s}^{-2}$ olmaktadır. Hidrolik sistemin toplam titreşim ivmesi ise makine üzerinde $60.02 \mathrm{~m} \mathrm{~s}^{-2}$, traktör sürücü koltuğuna $2.64 \mathrm{~m} \mathrm{~s}^{-2}$ olmaktadır. Yapılan Mann-Whitney U testine göre istatistiksel olarak her iki sistemin makine üzerindeki titreşim değerleri farkı önemli $(\mathrm{P}<0.05)$, sürücü koltuğunda oluşan titreşim değerleri farkı ise önemsiz $(\mathrm{P}>0.05)$ bulunmuştur.

Titreşime maruz kalan insanlarda omurga deformasyonları, mide rahatsızlıkları, zihinsel yük ve yorgunluk meydana gelmektedir (Sabancı, 1981; Akıncı ve ark., 1996; Babalık 2007; Sabancı ve Sümer 2011).

Ergonomi açısından titreşimin insan bedenine etkisi iki şekilde olmaktadır. Bunlar; ayak veya genellikle taşıtlarda oturma düzlemi ve ellerdir. Birinci halde tüm vücut titreşimi, ikinci halde el-kol titreşimi söz konusudur (Babalık, 2007).

Titreşimin sadece K değeri değil titreşimin etkidiği zaman da önemlidir. Birkaç dakika etkidiğinde hiçbir zararı olmayan bir titreşim daha uzun etkidiğinde sırası ile önce rahatı bozmakta, ardından performansı olumsuz etkilemekte ve en sonunda sağlığa da zararlı olmaktadır. Örneğin K değeri 12.5 olan titreşimde 8 dakikalık çalışmada hiçbir olumsuz etki olmazken, 30 dakikalık çalışmada huzursuzluk oluşmakta, 4 saatlik çalışmada performans düşmekte 8 saatlik çalışmada ise sağlığa zararlı olabilmektedir. Buna göre 10 dakikalık çalışmada üç yönden gelen titreşimlerde yaklaşı $\mathrm{K}=65$ iken ulaşılmaktadır (Babalık, 2007). Bu çalışmada ele alınan hidrolik sistemli makineyle çalışmada, sürücü koltuğunda oluşan titreşim değeri $\left(\mathrm{K}=2.64 \mathrm{~m} \mathrm{~s}^{-2}\right)$ sürücünün sağlığını olumsuz etkilemezken, mekanik sistemli makineyle çalışmada traktör sürücü koltuğunda oluşan titreşim değeri $\left(\mathrm{K}=3.23 \mathrm{~m} \mathrm{~s}^{-2}\right)$ sadece 5 saatlik çalışmaya kadar rahatlık sağlamakta, bu süreden sonra rahatsızlık oluşturmaktadır.

\section{Sonuç}

Ülkemizde kullanılan santrifüj gübre dağıtma makineleri granül haldeki gübreyi tarlaya dağıtmak için hareketi traktör kuyruk milinden mafsallı mil vasıtasıyla gerçekleştirmektedirler. Bu çalışmada, güç kaynağı olarak kuyruk miline alternatif olabilecek bir hidrolik sistem uygulaması oluşturulmuştur. $\mathrm{Bu}$ hidrolik motor uygulaması günümüz teknik şartlarına uygun ve ergonomik açıdan da daha avantajlı olabilmektedir. Hidrolik motor traktörden aldığı hidrolik güç ile santrifüjlü gübre dağıtma makinesini çalıştırmaktadır. Çalışmada elde edilen sonuçlar aşağıdaki şekilde özetlenebilir.

- Santrifüjlü gübre dağıtma makinesini mafsallı mil vasıtası ile çalıştırmak için gerekli güç torkmetre vasıtasıyla deney seti kurularak belirlenmiştir.

- Elde edilen veriler analiz edilerek gerekli güç tespit edilmiştir. Bu verilere dayanarak sistemin çalışması için gerekli olan hidrolik motor belirlenmiştir. 
- Hidrolik motorun seçimi gerçekleştirildikten sonra, traktör hidrolik sisteminden hidrolik motor vasıtasıyla santrifüjlü gübre dağıtma makinesine aktarabilmek için bir mekanik bağlantı kitinin imalatı gerçekleştirilmiştir.

- Hidrolik sistemin çalışması için gerekli olan hidrolik motor belirlendikten sonra, bu hidrolik motorla uyumlu bir biçimde çalışabilecek hidrolik bağlantı elemanları (hidrolik hortumlumlar, traktöre bağlantı için jaklar, hidrolik akışkanın basınç kontrolü için valfler vb.) belirlenmiştir.

- Sistemin oluşturulması için gerekli makine parçalarının belirlenmesi, seçimi, imalatı ve montaj işlemleri gerçekleştirildikten sonra iki sistemin karşılaştırılması için tarlada testler gerçekleştirilmiştir.

- Testlerde gübre dağılımı, yakıt tüketimi, gürültü ve titreşim değerleri ölçülmüştür.

- Her iki sistemde gübre dağılımında önemli bir fark görülmemiş, hidrolik sistemle çalışmada daha düşük yakıt tüketimi elde edilmiştir.

- Hidrolik sistemle çalışmada mekanik sisteme göre daha düşük gürültü ve titreşim değerlerinin oluştuğu belirlenmiştir.

$\mathrm{Bu}$ çalışma sonucunda oluşan çıktılar ışığında düşünülen öneriler aşă̆ı̆daki gibi sıralanabilir.

- Bu çalışma için geliştirilen mekanik bağlantı kiti, teknik ve maliyet yarar analizi yapıldıktan sonra ülkemizde hali hazırda bulunan santrifüj gübre dağıtma makinelerinin dönüşümü için de kullanılabilir.

- Bu çalışmada kullanılan tarım traktörü açık devre hidrolik sisteme sahiptir. Bu tip traktörlerin hidrolik sistemi traktörün motor devri belirli bir seviyeye gelene kadar gerekli hidrolik debiyi sağlamamaktadır. Hidrolik tahrik sistemine sahip santrifüj gübre dağıtma makinesinin traktörün motor çalışma devrinden bağımsız, kapalı hidrolik sistem mantığına göre çalışan ve hidrolik gücü yük durumuna göre arttırıp azaltan bir tarım traktörü ile çalıştırılması makinenin hem verimini hem de etkinliğini arttırabilecektir.

- Bilindiği üzere mekanik sistemle çalışan gübre dağıtma makinelerinde traktör kuyruk milinden gelen dönü gücü mafsallı bir mil vasıtası ile makine üzerine aktarılmaktadır. Bu mafsallı mil, mile dolanma riski ortaya çıkarmaktadır. Hidrolik sistemle çalışan santrifüj gübre dağıtma makinesinde bu tip bir durum olmadığından ergonomik açıdan rahatlıkla mekanik sistemle çalışan sisteme bir alternatif olarak önerilebilir.

- Traktör kuyruk milinden hareket alan diğer makinelerin de hidrolik motor uygulamaları ile çalıştırılmaları konusunda çalışmalar yapılabilir.

\section{Teşekkür}

Bu çalışma Kahramanmaraş Sütçü İmam Üniversitesi, Bilimsel Araştırma Projeleri Koordinasyon Birimi tarafından desteklenmiştir (Proje No: 2015/1-13YLS). 


\section{Kaynakça}

Akıncı, İ., Sabancı, A., Korucu, T., Ülker, K. (1996). Bazı Tarımsal İşlerde Traktör Titreşim Özellikleri. 6. Uluslararası Tarımsal Mekanizasyon ve Enerji Kongresi. (UTMEK'96). 2-6 Eylül, S.323-334. Ankara, Türkiye.

Anonim (2013). Çalışanların Gürültü İle İlgili Risklerden Korunmalarına Dair Yönetmelik. 28.07.2013 ve 28721Sayılı Resmi Gazete. Başbakanlık Basımevi, Ankara.

Anonim (2015). Titreșim Ölçüm Cihazları PCE-VM 3D, https://www.pce-instruments.com/turkish/oel uem-teknolojisi/oel uem cihazlarae/titre im-oel uem-cihazae -pce-instruments-titre im-oel uem-cihazlarae -pce-vm-3d-det 2212841.htm, (Erişim tarihi: 12.12.2015).

Anonim (2016). Tractor PTO Shaft Monitoring System, https://datum-electronics.co.uk/product/tractor-pto-shaft-power-monitoring-system/, (Erişim tarihi: 23.05.2016).

Anonim (2017a). Инновации AXIS-H Гидравлический привод, https://rauch.de/russisch/-4/axis-h/hydraulischer-antrieb.html, (Erişim tarihi: 15.05.2019)

Anonim (2017b). Druckmanometer PCE-SCJN Serie 400, https://www.warensortiment.de/datenblatt/datenblatt-druckmanometer-pce-scjnserie.pdf, (Erişim tarihi: 23.12.2017).

Anonim (2017c). Handheld Tachometer PCE-151, https://www.industrial-needs.com/manual/manual-pce-151.pdf, (Erişim tarihi: 23.12.2017).

Anonim (2018). hpa teknoloji, www.hpa.com.tr/tr/pdf/hidrolik/formüller.pdf, (Erişim tarihi: 23.12.2018).

Anonim (2019a). Ziraat Mühendisleri Odası (ZMO), http://www.zmo.org.tr/genel/bizden detay.php?kod=30873\&tipi=5\&sube=0, $($ Erişim tarihi: 25.05.2019).

Anonim (2019b). Hand-held Analyzer Type 2250-S - Brüel \& Kjær Sound \& Vibration, https://www.bksv.com/en/2250, (Erişim tarihi: 09.03.2019)

Anonim (2019c). Analytical Balance HR-250AZ, http://www.labequip.com/kz-content/images/xlarge/AND-HR250AZ-4decimal-Balance43181.jpg, (Erișim tarihi: 10.04.2019).

Anonim (2021). Türkiye İstatistik Kurumu (TUİK). Tarımsal İstatistik Verileri, http://www.tuik.gov.tr/, (Erişim tarihi:15.02.2021).

ASAE Standards, 45th Ed. (1998). S341.2. Procedure for measuring distribution uniformity and calibrating granular broadcast spreaders. St. Joseph, Mich.: ASAE.

Babalık, F.C. (2007). Mühendisler İçin Ergonomi İşbilim. Nobel Yayın Dağıtım Ltd. Ști., Yayın No: 831, Ankara.

Civelek, Ç., Gülsoylu, E. (2010). Bazı Tek Akslı Traktörlerle Çalışmada Tutamaklara Gelen Titreşimlerin Belirlenmesi. Ege Üniversitesi Ziraat Fakültesi Dergisi 47(3):257-263.

Çetin, M., Saygın, S., Demir, H. (2020). Tarım Sektörünün Çevre Kirliliği Üzerindeki Etkisi: Türkiye Ekonomisi İçin Bir Eşbütünleşme ve Nedensellik Analizi. Tekirdă̆ Ziraat Fakültesi Dergisi 17 (3): 329-345.

Demirgil, H. (2005). Non-Parametrik Testler, Editör: Şeref KALAYCI, SPSS Uygulamalı Çok Değişkenli İstatistik Teknikleri, Asil Yayın Dağıtım, Ankara.

Glover, J. W., Baird, J. V. (1973). Performance of spinner type fertilizer spreaders. Transactions of the ASAE 16(1): 48-51.

Grift, T. E. (2000). Spread pattern analysis tool (spat): I. Development and theoretical examples. Transactions of the ASAE 43(6): 1341-1350.

Özmerzi, A., Yaldız, O., Kürklü, A., Ertekin, C., Külcü, R. (2004). Tarım Makinaları İçin Mühendislik El Kitabı. Literatür Yayınları: 124, İstanbul.

Sabancı, A. (1981). Tarım Traktörlerinin Ergonomik Nitelikleri Üzerinde Bir Araştırma. TZDK Mesleki Yayınları, No: 1, Ankara.

Sabancı, A., Başçetinçelik, A., Özgüven, F., Öztürk, H. H., Say, S. M. (2010). Tarım Makinaları 1. Nobel Kit. Yayın Dağ.ve Paz. Ltd. Şti. Adana.

Sabancı, A., Sümer, S. K. (2011). Ergonomi. Nobel Akademik Yayıncılık Eğitim Danışmanlık Tic. Ltd. Şti., Yayın nu: 80, Ankara.

Safer (2008). Kırsal Alanda Çalışanlar İçin Daha Güvenli Tarım. Eğitim Modülleri. Santrifüj Gübre Dağıtma makineleri, S435-475.

Temel, U., Öztekin, Y.B. (2020). Tokat İlinde Kullanılan Bitki Koruma Makinelerinin Ürün Güvenliği Açısından Değerlendirilmesi. Tekirdăg Ziraat Fakültesi Dergisi 17(3): 276-284.

TS EN ISO 5349-1 (2005). Mekanik Titreșim-Kișilerin Maruz Kaldığg, Elle İletilen Titreșimin Ölçülmesi ve Değerlendirilmesi-Bölüm 1: Genel Kurallar. Türk Standartları Enstitüsü. 